\title{
Best Practice Through Broken Triangle, Square and Heart Can Grow Constitutional Awareness and Increase Citizenship Values
}

\section{Best Practice Melalui Broken Triangle, Square dan Heart Dapat Menumbuhkan Kesadaran Berkonstitusi dan Meningkatkan Nilai Kewarganegaraan}

\author{
Siti Fatimah* \\ SMP Negeri 2 WonosariGunungkidul, D.I. Yogyakarta, Indonesia
}

This Best Practice is the best experience in learning Citizenship Education. The subject matter of the Laws and Regulations in Indonesia. This Best Practice background is the result of teacher observations of students during PBM. The results of the study were students throwing garbage anywhere, wearing colorful shoes, male students with long hair, not having school identities installed, disrespecting teachers, not concentrating during teaching and learning activities. This behavior is a violation

OPEN ACCESS

ISSN 25482254 (online) ISSN 20893833 (print)

Edited by:

Mohammad Faizal Amir

Reviewedby:

Emy Pratiwi

${ }^{*}$ Correspondence:

Siti Fatimah

sitifatimijo@rocketmail.com

Received: 8 Juni 2021

Accepted: 21 Oktober 2021

Published: 17 November 2021

Citation:

Fatimah S, (2021) Best Practice

Through Broken Triangle,

Square and Heart Can Grow

Constitutional Awareness and

Increase Citizenship Values.

Pedagogia: Jurnal Pendidikan. 11:1.

doi: 10.21070/pedagogia.v11i1.1268 of school rules (constitution at school). This proves that students' awareness of the constitution in schools is still low. Many daily test scores are below the minimum completeness criteria (KKM). From this background, the learning method was changed by using the Broken Triangle and Square models. The Triangle and Square model aims to foster constitutional awareness and increase the value of Citizenship in class VIII E of SMP Negeri 2 Wonosari Gunungkidul in the Even Semester of the 2019/2020 Academic Year. After students learn with the Broken Triangle and Square models there are changes. This is evident from the research data. At the first meeting with the lecture model, constitutional awareness was $81.11 \%$. At the second meeting using the Broken Triangle and Square learning model, the awareness of the constitution was $97.41 \%$ and the third meeting the constitutional awareness was $98.52 \%$. Learning outcomes at the first meeting with the lecture model averaged 59.47, while at the second meeting with the Broken Triangle and Square model the average result was 66.0 and at the third meeting the average result was 86.13 . Thus, it shows that the Broken Triangle and Square learning model can be effective in raising awareness of the constitution and can increase value in Civics learning.

Keywords: Broken Triangle, Square, Heart, Constitutional Awareness, Learning Outcomes 
Best Practice ini merupakan pengalaman terbaik dalam pembelajaran Pendidikan Kewarganegaraan. Materi pelajaran tentang Peraturan Perundangan di Indonesia. Latar belakang Best Practice ini adalah hasil pengamatan guru terhadap peserta didik ketika PBM. Hasil penelitian membuktikan kesadaran peserta didik terhadap konstitusi di sekolah masih rendah. Hal ini dibuktikan dengan perilaku peserta didik membuang sampah sembarang, bersepatu warna-warni, peserta didik laki-laki rambut panjang, tidak dipasang identitas Sekolah, tidak hormat kepada guru, tidak konsentrasi ketika KBM. Perilaku tersebut merupakan pelanggaran terhadap tata tertib sekolah (konstitusi di sekolah). Nilai ulangan harian banyak yang dibawah kriteria ketuntasan minimal (KKM). Dari latar belakang tersebut, maka metode pembelajaran diubah dengan menggunakan model Broken Triangle, Square dan Heart. Model Triangle dan Square bertujuan untuk menumbuhkan kesadaran berkonstistusi dan meningkatkan nilai Kewarganegaraan di kelas VIII E SMP Negeri 2 Wonosari Gunungkidul di Semester Genap Tahun Pelajaran 2019/2020. Setelah peserta didik belajar dengan model Broken Triangle, Square dan Heart terdapat perubahan. Hal ini terbukti dari data hasil penelitian. Pada pertemuan pertama dengan model ceramah, kesadaran berkonstitusi $81,11 \%$. Pada pertemuan kedua dengan menggunakan model pembelajaran Broken Triangle, Square dan Heart kesadaran berkonstitusi 97,41 \% dan pertemuan ke-3 kesadaran berkonstitusi sebesar $98,52 \%$. Hasil pembelajaran pada pertemuan pertama dengan model ceramah hasil ratarata 59,47, sedangkan pada pertemuan kedua dengan model Broken Triangle, Square dan Heart diperoleh hasil rata-rata 66,0 dan pada pertemuan ketiga hasil rata-rata 86,13. Dengan demikian menunjukkan bahwa model pembelajaran Broken Triangle, Square dan Heart dapat efektif untuk menumbuhkan kesadaran berkonstitusi dan dapat meningkatkan nilai dalam pembelajaran PPKn. 


\section{PENDAHULUAN}

Pendidikan Pancasila dan Kewarganegaraan merupakan salah satu mata pelajaran yang diamanatkan dalam Undang-Undang Pendidikan Nomor 20 Tahun 2003, yaitu untuk mengembangkan potensi peserta didik agar menjadi manusia yang beriman dan bertaqwa kepada Tuhan yang Maha Esa, berakhlak mulia, sehat, berilmu, cakap, kreatif, mandiri, dan menjadi warga Negara yang demokratis serta bertanggungjawab. Dengan demikian mata pelajaran PPKn memiliki kedudukan yang sangat strategis untuk pembentukan warga negara yang memiliki kepribadian sesuai dengan Pancasila dan UUD NRI tahun 1945, dan berperan aktif dalam menegakkan Pancasila sebagai Dasar Negara (2015).

Karakteristik PPKn untuk mengembangkan potensi kognisi, afeksi dan psikomotorik peserta didik. Ranah afeksi menjadi titik tekan untuk dikembangkan dalam mata pelajaran ini. PPKn merupakan mata pelajaran sebagai wahana untuk mengembangkan nilai dan moral peserta didik yang berakar pada budaya bangsa Indonesia, yang diharapkan dapat diwujudkan dalam bentuk perilaku kehidupan sehari-hari, baik sebagai individu maupun selaku warga masyarakat, warga negara dan makhluk ciptaan Tuhan Yang Maha Esa. Selain itu PPKn membekali peserta didik dengan budi pekerti, pengetahuan dan kemampuan dasar terutama yang berhubungan dengan negara, serta pendidikan pendahuluan bela negara agar menjadi warga negara yang dapat diandalkan oleh bangsa dan negara.

Dewasa ini sudah banyak terjadi perubahan karakter dan sosial di kalangan para peserta didik. Ini merupakan pengaruh dari globalisasi dan perkembangan teknologi yang pesat. Mereka mudah mendapatkan informasi-informasi dari dunia maya seperti game online, youtube. Informasi tersebut mereka serap begitu saja, tanpa disesuaikan dengan situasi, kondisi, usia, dan kebutuhan. Hal ini akan merusak kebiasaan, pola pikir anak pada khususnya dan merusak moral serta kepribadian bangsa Indonesia. Kebiasaan-kebiasaan yang tidak dikendalikan akan berakibat muncul pelanggaranpelanggaran di lingkungan keluarga, sekolah maupun masyarakat.

Pelanggaran yang terjadi di lingkungan keluarga antara lain rendahnya rasa hormat kepada orang tua, bahkan ada yang berani melawan tehadap orangtua ketika di nasehati. Pelanggaran juga terjadi di lingkungan masyarakat seperti tawuran antar pelajar, maraknya pengguna obat terlarang, tindakan kriminal, pelanggaran HAM, dan masih banyak lagi. Pelanggaran yang terjadi di sekolah misalnya bermain Game saat belajar sehingga tugas sekolah tidak dikerjakan, mengendarai sepeda motor pada hal belum memiliki SIM, membuang sampah di sembarang tempat, memiliki potongan rambut, sepatu dan baju ala selebritis. Peserta didik tidak konsentrasi dengan pelajaran, saling bicara, keluar masuk ruang kelas tanpa izin guru. Mereka di kelas bertingkah laku bebas seolah-olah tidak ada aturan atau tata tertib. Perilaku tersebut disebabkan oleh kurangnya pemahaman, kesadaran, dan ketaatan peserta didik terhadap konstitusi atau aturanaturan yang berlaku di lingkungan sekolah, masyarakat, bangsa dan negara.

Menghadapi permasalahan ini guru tidak mungkin hanya menggunakan metode ceramah saja dalam melaksanakan kegiatan pembelajaran tetapi harus mencoba menggunakan model yang melibatkan peserta didik secara aktif, inovatif, kreatif dan menyenangkan, gembira dan berbobot (PAIKEM GEMBROT). Dengan demikian peserta didik termotivasi untuk mengikuti pembelajaran PPKn yang ditandai dengan aktivitas peserta didik yang meningkat sehingga ketuntasan belajar dapat tercapai.

Berdasarkan latar belakang, dan identifikasi masalah yang dikemukakan di atas, maka perumusan masalah adalah apakah model pembelajaran Broken Triangle, Square dan Heart dalam pembelajaran PPKn dapat menumbuhkan kesadaran berkonstitusi dan dapat meningkatkan nilai Kewarganegaraan bagi peserta didik peserta didik di VIII E SMPN 2 Wonosari Gunungkidul di Semester Genap Tahun Pelajaran 2019/2020? Tujuan Penulisan ini adalah untuk mengetahui bahwa model pembelajaran Broken Triangle, Square dan Heart dalam pembelajaran PPKn dapat menumbuhkan kesadaran berkonstitusi dan dapat meningkatkan nilai Kewarganegaraan bagi peserta didik peserta didik di VIII E SMPN 2 Wonosari Gunungkidul di Semester Genap Tahun Pelajaran 2019/2020.

Manfaat penulisan bagi peserta didik adalah dapat menumbuhkan kesadaran berkonstitusi dan meningkatkan nilai peserta didik. bagi guru dapat memperbaiki kinerja guru dan salah satu referensi untuk meningkatkan kualitas pembelajaran, dan bagi sekolah dapat mendukung tercapainya visi dan misi sekolah, serta bagi Dinas Pendidikan adalah dapat mendukung tercapainya mutu pendidikan baik di daerah maupun di tingkat.

\section{METODE}

\section{Pengertian Kesadaran Berkonstitusi}

Menurut Pimpinan RI (2016) Konstitusi adalah hukum dasar yang dijadikan pegangan dalam penyelenggaraan suatu negara. Konstitusi dapat berupa hukum dasar tertulis yang lazim disebut Undang-Undang Dasar, dan dapat pula tidak tertulis. Kesadaran berkonstitusi secara konseptual diartikan sebagai kualitas pribadi seseorang yang memancarkan wawasan, sikap, dan perilaku yang bermuatan cita- cita dan komitmen luhur kebangsaan dan kebernegaraan Indonesia. Winataputra (2007) Kesadaran berkonstitusi merupakan salah satu bentuk keinsyafan warga negara akan pentingnya mengimplementasikan nilainilai konstitusi.

Menurut Suseno (1985) Kesadaran berkonstitusi merupakan salah bagian dari kesadaran moral. Sebagai bagian dari kesadaran moral, kesadaran konstitusi mempunyai tiga unsur pokok yaitu: (1) Perasaan wajib atau keharusan untuk melakukan tindakan bermoral yang sesuai dengan konstitusi negara itu ada dan terjadi di dalam setiap sanubari warga negara, siapapun, di manapun dan kapanpun; (2) Rasional, kesadaran moral dapat dikatakan rasional karena berlaku umum, lagi pula terbuka bagi pembenaran atau penyangkalan. Dengan demikian kesadaran berkonstitusi merupakan hal yang bersifat rasional dan dapat dinyatakan pula sebagai hal objektif yang dapat diuniversalkan, artinya dapat disetujui, berlaku pada setiap waktu dan tempat bagi setiap warga negara; dan (3) Kebebasan, atas kesadaran moralnya, warga negara bebas untuk mentaati berbagai peraturan perundangundangan yang berlaku di negaranya termasuk ketentuan konstitusi negara. 


\section{Pengertian Pembelajaran}

Pembelajaran adalah usaha guru membentuk tingkah laku yang diinginkan dengan menyediakan lingkungan atau stimulus Hamdani (2010). Hamalik (2020) berpendapat bahwa pembelajaran adalah suatu kombinasi yang tersusun meliputi unsur-unsur manusiawi, material, fasilitas, perlengkapan, dan prosedur yang saling mempengaruhi mencapai tujuan pembelajaran. Pembelajaran dapat diartikan sebagai proses modifikasi dalam kapasitas manusia yang bisa dipertahkankan dan ditingkatkan levelnya Miftahul (2020). Pembelajaran adalah merupakan sarana untuk memungkinkan terjadinya proses belajar adalam arti perubahan perilaku individu melalui proses mengalami sesuatu yang diciptakan dalam rancangan proses pembelajaran Ngalimun (2016). Pembelajaran adalah usaha perubahan yang dilakukan secara sungguh-sungguh dan sistematis, mental serta dana, pancaindra, otak dan anggota tubuh lainya, serta aspek-aspek kejiwaan, seperti intelegensi, bakat, motivasi, minat, dan sebagainya Salahudin (2013).

Dari beberapa pendapat diatas disimpulkan bahwa pembelajaran adalah sebuah proses yang dilakukan oleh guru dan peserta didik sehingga terjadi proses belajar dalam arti adanya perubahan perilaku individu peserta didik itu sendiri.

\section{Pengertian Model Pembelajaran}

Model pembelajaran yaitu kerangka konseptual yang melukiskan prosedur yang sistematis dalam pengorganisasikan pengalaman belajar untuk mencapai tujuan belajar tertentu dan berfungsi sebagai pedoman bagi para perancang pembelajaran dan para pengajar dalam merencanakan aktivitas belajar mengajar Al_Tabany (2017). Menurut Rusman (2016) bahwa model pembelajaran adalah suatu rencana atau pola yang dapat digunakan untuk membentuk kurikulum (rencana pembelajaran jangka panjang), merancang bahan-bahan pembelajaran, dan membimbing pembelajaran di kelas atau yang lain. Model pembelajaran dapat dijadikan pola pilihan, artinya para guru boleh meilih model pembelajaran yang sesuai dan efisien untuk mencapai tujuan pendidikannya. Sedangkan menurut Sani (2013) model pembelajaran adalah sebuah model pembelajaran dikembangkan sesuai tahapan pembelajaran, sistem sosial, prinsip reaksi, dan sistem pendukung untuk membantu peserta didik dalam membangun/mengkontruksi pengetahuannya melalui interaksi dengan sumebr belajar. Model pembelajaran memiliki sintaks yang menunjukkan kegiatan apa saja yang perlu dilakukan oleh guru dan peserta didik mulai dari awal pembelajaran sampai kegiatan akhir.

\section{Pengertian Permainan}

Gunarso (1990) memberikan pendapat bahwa permainan merupakan suatu kegiatan yang dicari dan dilakukan oleh seseorang demi kegiatan itu sendiri, karena kegiatan tersebut memberi kesenangan. Smaldino (2011) berpendapat bahwa, permainan memberikan lingkungan kompetitif yang di dalamnya para pemelajar mengikuti aturan yang telah ditetapkan saat mereka berusaha mencapai tujuan pendidikan yang menantang. Ahmadi (1991) mengemukakan bahwa suatu permainan yang mengandung keasyikan dan dilakukan atas kehendak sendiri, bebas tanpa paksaan dengan tujuan untuk memperoleh kesenangan pada waktu melakukan kegiatan tersebut. Pendapat Latuheru (1998), permainan sebagai model pembelajaran adalah suatu bentuk kegiatan dimana peserta yang terlibat didalamnya bertindak dengan aturan-aturan yang ditetapkan untuk mencapai suatu tujuan yaitu tujuan pembelajaran. Selain itu, permainan dapat menimbulkan berbagai macam emosi, rasa gembira, suka dan duka. Sulaiman (1950) ada tiga corak permainan yaitu: 1) untuk kemajuan jasmani, 2) untuk kemajuan intelek, dan 3) untuk kemajuan rohani dan pembentukan moral.

Berdasarkan pendapat-pendapat di atas dapat kita simpulkan bahwa unsur kesenangan, kepuasan, spontanitas, dan kebebasan dapat melengkapi kegiatan permainan. Model permainan, dapat diberikan pada sekolah tingkat pertama (SMP) dan harus disesuaikan dengan fase perkembangannya. Peserta didik SMP merupakan fase remaja awal yang masih membutuhkan permainan untuk mengembangkan kreatifitas, sikap, moral, dan kemampuannya. Permainan ini dapat diaplikasikan dengan peserta didik melakukan kegiatan permainan dalam proses belajar mengajar yang dapat dilakukan secara individual maupun kelompok.

Penggunaan permainan sebagai model pembelajaran dapat dijadikan sebagai selingan atau variasi dari model-model yang biasa dipakai oleh guru sehingga peserta didik tidak akan bosan dan merasa jenuh. Untuk menjadikan permainan sebagai model pembelajaran, permainan tersebut harus menjurus pada pencapaian kemampuan akademis. Oleh karena itu pemanfaatan permainan sebagai model pembelajaran harus dipersiapkan dengan sebaiknya-baiknya agar tujuan pembelajaran dapat tercapai. Sehingga tujuan permainan tidak hanya mencari kesenangan saja tetapi ada tujuan yang hendak dicapai yaitu tujuan pembelajaran.

\section{Permainan Model Broken Triangle, Square dan Heart}

Menurut Komalasari (2010), model Broken/ Triangle/ Square/ Heart disebut juga dengan puzzle. Melalui model pembelajaran ini, siswa harus mengelompokkan materi yang terpisah-pisah (pecah-pecah) ke dalam satu kesatuan konsep materi yang terbentuk dalam segitiga/bujur sangkar/hati. Menurut Sukrima (2014) metode Broken Square yaitu cara penyusunan pecahan-pecahan bujur sangkar yang dilakukan oleh empat atau lima kelompok menjadi bentuk bujur sangkar. Sedangkan menurut Sundari (2016), model Broken Triangle, Square dan Heart adalah sebuah model yang umumnya digunakan pada materi yang berisi uraian dalam bentuk optionoption. Model ini menggunakan penekanan latihan soal berupa permainan yang dikerjakan secara berkelompok. Dalam model pembelajaran ini perlu adanya kerja sama antar anggota kelompok untuk saling membantu teman sekelompok dapat berpikir kritis sehingga dapat lebih mudah dalam mencari penyelesaian soal.

Berdasarkan pendapat ahli tersebut maka dapat disimpulkan bahwa model Broken Triangle dan Squre adalah alat yang digunakan untuk membantu pengajaran PPKN terutama dalam penanaman konsep, nilai bahkan membawa perubahan tingkah laku peserta didik. Media ini dibuat dalam bentuk pecahan-pecahan segiempat yang akan disusun menjadi sebuah konsep, dikerjakan oleh peserta didik dalam bentuk berkelompok. Dengan menggunakan model Broken Triangle, Square dan Heart ini diharapkan hasil belajar peserta didik dapat meningkat, karena dalam media ini mengandung unsur 
permainan yang memungkinkan anak belajar sambil bermain sehingga pembelajaran menjadi menyenangkan.

Langkah - Langkah Model Broken Triangle, Square dan Heart Adapun langkah-langkah model Broken Triangle, Square dan Heart sebagai berikut Sundari (2016). 1. Guru menyiapkan beberapa bentuk segitiga, bujur sangkar dan hati yang dipecah kedalam beberapa kartu. Masing-masing kartu berisi satu option uraian dari konsep materi dan akan membentuk satu kesatuan (utuh) bentuk tertentu segitiga, bujur sangkar dan hati; 2. Setiap kolompok peserta didik mendapat beberapa potongan kartu pecahan dari segitiga, bujur sangkar dan hati; 3. Setiap kelompok peserta didik membentuk satu kesatuan kartu kedalam segitiga, bujur sangkar dan hati yang tepat sehingga membentuk satu kesatuan konsep materi; 4. Setiap kelompok peserta didik yang dapat membentuk satu kesatuan kartu pecahan segitiga, bujur sangkar dan hati sebelum batas waktu diberi poin; 5 . Perwakilan masing-masing kelompok peserta didik menempelkan satu kesatuan kartu pecahan segitiga, bujur sangkar dan hati di papan tulis; 6. Guru dan peserta didik mengklarifikasi hasil karya peserta didik dalam membentuk segitiga, bujur sangkar dan hati konsep materi; 7. Kesimpulan/ penutup.

Kelebihan dan Kekurangan Model Broken Triangle, Square dan Heart. Kelebihan dari model Broken Triangle, Square dan Heart ini adalah sebagai berikut Sundari (2016). 1) Setiap anggota kelompok dilatih untuk memiliki rasa bertanggung jawab atas segala sesuatu yang dikerjakan dalam kelompoknya; 2) Model pembelajaran ini akan memungkinkan peserta didik untuk belajar sambil bermain. Mereka dapat berkreasi sekaligus belajar dan berpikir, mempelajari sesuatu secara santai dan tidak membuatnya stres atau tertekan; 3) Selain untuk menimbulkan kegembiraan dan melatih keterampilan tertentu, model ini juga dapat memupuk rasa solidaritas dalam kelompok; 4) Materi yang diberikan melalui salah satu model permainan ini biasanya mengesankan dan sulit untuk dilupakan; 5) Sifat kompetitif dalam model ini dapat mendorong peserta didik berlombalomba untuk maju.

Sedangkan kekurangan dari model Broken Triangle, Square dan Heart adalah sebagai berikut: 1) Pembelajaran ini terkadang sulit dalam merencanakannya, oleh karena terbentur dengan kebiasaan peserta didik dalam belajar; 2) Terkadang dalam mengimplementasikannya, memerlukan waktu yang panjang sehingga guru sulit menyesuaikannya dengan waktu yang telah ditentukan; 3) Selama kriteria keberhasilan belajar ditentukan oleh kemampuan peserta didik menguasai materi pelajaran, maka pembelajaran ini akan sulit di implementasikann oleh guru; 4) Model permainan seperti ini biasanya menimbulkan suara gaduh. Hal tersebut jelas akan mengganggu kelas yang berdekatan

\section{HASIL DAN PEMBAHASAN}

SMP Negeri 2 Wonosari menerapkan Kurikulum 2013 sejak tahun pelajaran 2015/2019. Proses belajar mengajar dilaksanakan pagi hingga siang hari mulai dari pukul 07.00 WIB sampai dengan 15.00 WIB, kecuali hari Jumat pukul 16.00 WIB. Kegiatan didukung dengan ketersediaan fasilitas dan sarana pembelajaran yang memadai: perpustakaan, laboratorium dan terbukanya jaringan internet sebagai sumber belajar. Jumlah peserta didik ada 630, yang terbagi dalam 21 rombongan belajar.

Pada saat proses pembelajaran di kelas, sering terjadi peserta didik kurang fokus. Hal ini di karenakan metode yang digunakan dalam proses pembelajaran kurang di minati oleh anak. Sementara tujuan dari pembelajaran itu sendiri adalah terjadinya proses belajar dalam arti perubahan perilaku individu melalui proses mengalami sesuatu yang diciptakan dalam rancangan proses pembelajaran. Hasil yang diperoleh belum sesuai harapan. Peserta didik kelas VIII E SMPN 2 Wonosari di Semester Genap Tahun Pelajaran 2019/2020 terutama peserta didik yang laki-laki, sebagian besar melakukan pelanggaran di dalam kelas. Contoh yang tindakan pelanggaran antara lain terlambat masuk kelas sehingga penulis harus menunggu; saling mengobrol dengan peserta didik lainnya dengan topik yang berbeda saat dari yang dijelaskan oleh guru menghargai guru yang mengajar sehingga penulis selalu mengulang-ulang materi; keluar masuk kelas tanpa aturan dan tanpa izin guru di kelas; tidur ketika proses kegiatan belajar mengajar; membuang sampah sembarang sehingga lantai kelas kotor

Perilaku peserta didik menunjukkan sikap bahwa kesadaran terhadap peraturan tata tertib SMPN 2 Wonosari atau konstitusi sekolah masih rendah dengan sehingga merugikan semua Peserta didik. Peristiwa itu berlangsung hampir satu semester. Hal ini tidak hanya dirasakan oleh penulis pribadi tetapi hampir semua guru yang mengajar di kelas tersebut merasa kewalahan. Setiap guru akan memulai kegiatan pembelajaran, guru harus memberikan nasihat terlebih dahulu kepada peserta didik mengenai tata tertib sekolah. Wali kelas dan semua guru yang mengajar sudah berusaha membina apalagi guru Bimbingan Konseling yang dengan sabar dan penuh kasih sayang selalu memberi nasihat. Menurut teman-teman guru, ketika proses belajar mengajar berlangsung semua model sudah diterapkan, namun belum ada perubahan sikap yang positif dari peserta

Untuk mencapai tujuan pembelajaran maka metode ceramah di kombinasi dengan model pembelajaran yang lain agar dapat menarik bagi peserta didik. Model pembelajaran yang dapat meningkatkan perubahan perilaku dan nilai diantaranya adalah model Broken Triangle, Square dan Heart.

\section{Alasan Pemilihan model Broken Triangle, Square dan Heart}

Kelas VIII E SMPN 2 Wonosari di Semester Genap Tahun Pelajaran 2019/2020 dikategorikan sebagai kelas yang ramai. Kegiatan belajar mengajar kurang kondusif. Penulis mencoba dengan model pembelajaran yang lain. Model yang penulis pilih ada model permainan. Peserta didik dapat belajar sambil bermain. Penggunaan permainan sebagai model pembelajaran dapat dijadikan sebagai selingan atau variasi dari model-model yang biasa dipakai oleh guru sehingga peserta didik tidak akan bosan dan merasa jenuh. Penulis memilih model pembelajaran Broken Triangle, Square dan Heart, ketika mengajar di kelas VIII E SMPN 2 Wonosari di Semester Genap Tahun Pelajaran 2019/2020.

Penulis menggunakan model Broken Triangle, Square dan Heart ketika membahas materi Tata Urutan Peraturan 
Perundang-undang, berlangsung selama dua kali pertemuan atau 6 jam pelajaran. Berdasarkan pengalaman yang sudah penulis dapatkan, model Broken Triangle, Square dan Heart penulis dapat menumbuhkan kesadaran berkonstitusi. Kesadaran berkonstitusi merupakan salah satu bagian dari kesadaran moral. Model Broken Triangle, Square dan Heart memecahkan masalah yang terjadi pada saat penulis mengajar di kelas yang kurang kondusif. Langkah pertama, penulis menjelaskan materi secara singkat tentang Memaknai Peraturan Perundang Undangan yaitu Makna Peraturan Perundang Undangan, yang dijabarkan menjadi: Pengertian Perundangan-undangan Nasional; Tata Urutan Perundangan-undangan Nasional. Langkah kedua, menjelaskan langkah-langkah pembelajaran model permainan Broken Triangle, Square dan Heart dengan memberi contoh model Broken Triangle, Square dan Heart. Pada langkah ketiga, penulis menyiapkan peralatan yang dibutuhkan dalam media permainan pembelajaran ini, antara lain: Kertas HVS warna kosong, Gunting, Lem kertas, Spidol warna. Langkah keempat, penulis mengkondisikan peserta didik untuk melakukan diskusi dengan kegiatan scenario kegiatan seperti berikut ini.

Langkah Guru diawali dengan membuka pelajaran; melakukan pengabsenan terhadap kehadiran peserta didik; mengecek kebersihan kelas; mengkondisikan kesiapan proses pembelajaran; menyampaikan informasi tentang materi "Tata Urutan Perundangan di Indonesia" secara klasikal dengan model informasi dan tanya jawab; menjelaskan kompetensi dasar yang akan dicapai.

Langkah inti guru membagi kelas menjadi 6 kelompok, masing-masing 5 anggota; guru mempersiapkan beberapa bentuk segitiga, bujur sangkar dan hati yang dipecah kedalam beberapa kartu atau puzzle. Masing-masing kartu berisi satu option uraian dari konsep materi dan akan membentuk satu kesatuan (utuh) bentuk tertentu segitiga dan bujur sangkar; membagi Lembar Kerja dan melakukan penilaian terhadap aktivitas Peserta didik dalam proses pembelajaran ini dengan menggunakan lembar pengamatan dalam proses pembelajaran; memberikan pengarahan dan pengawasan kepada peserta didik. Peserta didik melakukan tanya jawab dengan guru tentang permainan dalam pembelajaran Broken Triangle, Square dan Heart yang di buat; mengamati dengan menggunakan lembar observasi dan menilai hasil kerja Broken Triangle, Square dan Heart. Langkah penutup guru menyimpulkan materi secara bersama-sama setelah presentasi selesai dan melakukan penilaian post test.

\section{Kegiatan Peserta didik.}

Kegiatan peserta didik diawali dengan berdoa, kemudian membagi diri menjadi 6 kelompok, masing-masing 5 anggota; mengerjakan lembar kerja mulai bermain menyusun puzzle atau potongan-potongan kartu membentuk satu kesatuan (utuh) bentuk tertentu segitiga dan bujur sangkar. Bentuk segitiga dan bujur sangkar dapat tersusun dengan benar sehingga menjadi kalimat yang bermakna; mencari urutan yang benar tentang urutan peraturan perundangan di Indonesia dalam tulisan kertas yang dipotong-potong. Setelah puzzle tertata dan berbentuk segitiga atau bujur sangkar, kemudian di lem dan di tempel dalam kertas HVS, supaya rapi dan tidak berubah-ubah; membuat ringkasan materi Tata Urutan Perundangan di Indonesia; mempresentasikan hasil kinerja sesuai peraturan ( konstitusi) secara berkelompok yang sudah disepakati bersama di depan kelas.

Tata cara presentasi atau aturan-aturan (konstitusi) yang harus ditaati yaitu pemaparan satu kelompok selama 10 menit; waktu pemaparan dibuka dan ditutup dengan berdoa atau salam; pemaparan hasil diskusi oleh kelompok, ada pembagian tugas sebagai presenter, moderator, menjawab pertanyaan; penyampaian pertanyaan dari kelompok secara bergantian; saling menghormati dan menghargai pendapat walaupun berbeda; membuat kesimpulan dengan dituliskan di dalam lembar tersendiri; dikumpulkan untuk dilakukan penilaian. Dalam kegiatan diskusi pembelajaran dengan menggunakan model Broken Triangle, Square dan Heart ada kesepakatan aturan yang harus dipahami dan ditaati oleh peserta didk. Di samping itu ada penanaman nilai dari pasal 28 Undang Undang Dasar 1945, yaitu kemerdekaan berserikat dan berkumpul, mengeluarkan pikiran dengan lisan dan tulisan dan sebagainya ditetapkan dengan undang-undang.

\section{Hasil yang Dicapai dari Model permainan Broken Triangle, Square dan Heart}

Setelah melaksanakan pembelajaran dengan model Broken Triangle, Square dan Heart, peserta didik mendapat pengalaman dan pemahaman dalam mentaati peraturan sekolah. Kesadaran peserta didik terhadap konstitusi ada peningkatan. Peningkatan dalam berkonstitusi dapat dilihat dari hasil belajar peserta didik secara kognitif maupun afektif. Cakupan materi Tata Urutan Peraturan Perundangan yang berkaitan dengan peningkatan kesadaran berkonstitusi Peserta didik adalah UUD 1945 pasal 28. Selengkapnya secara ringkas dapat diuraikan sebagai berikut.

\section{Nilai Aspek Afektif}

Materi Tata Urutan Peraturan Perundang Undangan yang membahas tentang Perundangan di Indonesia dengan menggunakan model Broken Triangle, Square dan Heart ternyata dapat merubah terhadap kondisi peserta didik dalam proses pembelajaran terutama pada sikap. Materi Perundangan di Indonesia memberikan penjelasan tentang bagaimana proses pembuatan sebuah peraturan atau kebijakan, termasuk peraturan di sekolah. Materi perundangan di Indonesia juga mengatur sikap warga negara yang baik. Kondisi awal yang terjadi di kelas VIII E, banyak peserta didik terlambat masuk kelas, peserta didik laki-laki memiliki rambut panjang, baju seragam tanpa identitas, sepatu warna-warni, saling mengobrol diluar materi pelajaran, kurang menghargai guru di kelas, keluar masuk kelas tanpa aturan, tidur ketika proses belajar mengajar berlangsung.

Setelah materi perundangan nasional ini selesai dibahas, perilaku pesera didik mulai ada perubahan ke arah positif. Peserta didik mulai tumbuh kesadarannya terhadap peraturan sekolah. Mereka sudah berusaha membuang sampah pada tempatnya sehingga suasana lingkungan sekolah bersih, sepatu sudah tidak berwarna-warni, potongan rambut rapi, seragam sekolah sesuai identitas SMPN 2 Wonosari, peserta didik lebih menghargai guru di kelas ketika KBM, peserta didik lebih berkonsentrasi dengan materi pelajaran, dan tidak ada yang tidur di dalam kelas. Sebagai data pendukung adanya 
peningkatan kesadaran Peserta didik terhadap peraturan sekolah atau konstitusi dapat dilihat pada tabel 1

\section{[Table 1 about here.]}

Dari data tabel 1 dapat dijelaskan bahwa kesadaran berkonstitusi pada pertemuan pertama $81,43 \%$., pada pertemuan kedua $97,14 \%$ dan pertemuan ketiga 98,57\%. Dengan demikian ada peningkatan terhadap kesadaran berkonstitusi. Dari tabel 1 disajikan dengan grafik 1

[Figure 1 about here.]

\section{Nilai Hasil Belajar Peserta didik Aspek Pengetahuan}

Di samping itu hasil dalam proses belajar ada perbedaan ketika menggunakan model ceramah dengan model Broken Triangle, Square dan Heart. Pada pertemuan pertama dengan metode ceramah nilai rata-rata 59,47, pertemuan kedua dengan model pembelajaran Broken Triangle, Square dan Heart, rata-rata 66,0 dan pertemuan ketiga 86,13. Dengan demikian terlihat perubahan yang signifikan. Hasil nilai aspek pengetahuan dapat dilihat dalam tabel berikut

\section{[Table 2 about here.]}

Dari Tabel 2 hasil nilai rata-rata pengetahuan dapat di buat grafik sebagai berikut

\section{[Figure 2 about here.]}

Melihat perbedaan skor dalam tabel di atas, menunjukkan bahwa dengan model pembelajaran Broken Triangle, Square dan Heart lebih efektif digunakan dalam pembelajaran Pendidikan Pancasila dan Kewarganegaraan. Peserta didik telah menyadari mengapa peraturan dibuat, untuk seluruh warga sekolah dan untuk memberikan hak dan kewajiban bagi warga sekolah. Peserta didik senang mengikuti pembelajaran dengan model Broken Triangle, Square dan Heart peserta didik dapat belajar sambil bermain. Kelompok kerja tampak aktif dan dapat menyampaikan presentasi dengan bahasa yang sopan serta mau menghargai pendapat teman. Dengan model pembelajaran Broken Triangle, Square dan Heart, peserta didik merasa sangat berkesan dan lebih mudah dalam mengingat materi Pendidikan Pancasila dan Kewarganegaraan.

Pembelajaran dengan model Broken Triangle, Square dan Heart membuat pesera didik lebih aktif, inovatif, kreatif, senang dan gembira dalam mengikuti kegiatan pembelajaran. Dengan menggunakan media permainan model Broken Triangle, Square dan Heart dalam proses pembelajaran diharapkan agar peserta didik dapat tumbuh kesadaran berkonstitusi untuk bekerja sama, bertanggung jawab, saling membantu dalam memecahkan masalah dan saling mendorong untuk berprestasi yang perilakunya tercermin dalam kehidupan sehari-hari.

Penggunaan model Broken Triangle, Square dan Heart dalam pembelajaran pendidikan kewarganegaraan membuat peserta didik lebih banyak melakukan kegiatan belajar seperti berdiskusi, mengemukakakan pendapat, berkerjasama, dan menyimpulkan hasil diskusi. Hal ini menjadikan proses belajar dan mengajar menjadi menarik sehingga mampu meningkatkan keterampilan kewarganegaraan (civic skills) untuk belajar Pendidikan Kewarganegaraan. Model Broken Triangle, Square dan Heart juga mampu meningkatkan taraf berpikir Peserta didik dari konkret ke abstrak dan dari yang sederhana ke kompleks.

Penggunaan model Broken Triangle, Square dan Heart jika digunakan secara kontinyu maka akan meningkatkan kualitas pembelajaran yang pada akhirnya akan meningkatkan prestasi belajar. Model pembelajaran Broken Triangle, Square dan Heart lebih efektif dan menarik, serta dapat menumbuhkan minat belajar peserta didik.

\section{Kendala-Kendala yang Dihadapi dalam Melaksanakan Model Broken Triangle, Square dan Heart}

Dalam proses pembelajaran dengan model Broken Triangle, Square dan Heart terdapat kendala bagi Peserta didik, yaitu kurang memahami tata cara membuat Broken Square; kurang percaya diri dalam kerja kelompok; kurang kompak. Kendala dari guru atau penulis yaitu tidak cukup waktu untuk melakukan bimbingan per kelompok; kurang menguasai kelas, karena ada 6 kelompok; waktu yang disediakan terbatas 80 menit.

\section{Faktor-Faktor yang Mendukung}

Faktor-faktor yang mendukung dalam keberhasilan pelaksanaan kegiatan pembelajaran dengan model Broken Triangle, Square dan Heart adalah peserta didik sudah termotivasi dan menampakan kegembiraan dalam belajar; sikap terbuka guru mengurangi rasa tertekan Peserta didik dalam mengikuti pembelajaran; peserta didik benar-benar mengalami belajar yang menyenangkan; peserta didik mengerjakan tugas dengan gembira, maka berdampak pada kesiapan Peserta didik untuk mengerjakan tugas dan mempersiapkan alat dengan antusias; lebih aktif dan kreatif selama proses pembelajaran; menjadi lebih komunikatif; berlomba untuk mendapatkan nilai yang terbaik; konsentrasi Peserta didik sangat tinggi.

\section{KESIMPULAN}

Berdasarkan proses penelitian yang telah dilakukan dapat disimpulkan bahwa proses pembelajaran Pendidikan Pancasila dan Kewarganegaraan dengan mengunakan model pembelajaran Broken Triangle, Square dan Heart yang dilaksanakan dengan terencana dan terprogram sangat menarik dan menyenangkan. Hasil belajar dapat meningkat. Kesadaran berkonstitusi peserta didik, terlihat dalam kegiatan diskusi kelas. Peserta didik menunjukkan perilaku mentaati aturan permainan dalam pembelajaran, dan menyampaikan presentasi hasil diskusi kelompok sesuai dengan pembagian tugas. Masing-masing dapat menunjukkan sikap kerjasama dan tanggungjawab dalam kegiatan diskusi kelompok. Di samping itu, penerapan model Broken Triangle, Square dan Heart dapat meningkatkan nilai atau hasil belajar aspek pengetahuan untuk mata pelajaran Pendidikan Kewarganegaraan di Kelas VIII E SMP Negeri 2 Wonosari di 
Semester Genap Tahun Pelajaran 2019/2020.)

\section{UCAPAN TERIMA KASIH}

Penulis tak lupa mengucapkan terimakasih kepada Bapak Purwanto, M.Pd.Si, selaku Kepala SMPN 2 Wonosari Gunungkidul yang telah memberi saran, bimbingan, izin dan kesempatan untuk melakukan penulisan Best Practice ini. Kepada teman-teman guru yang sudah membantu dalam penulisan Best Practice ini. Kepada seluruh peserta didik kelas VIII E tahun pelajaran 2019/2020, yang sudah membantu dan melancarkan kegiatan penelitian dan penulisan Best Practice ini. Kepada seluruh pihak yang tidak bisa disebutkan satu persatu yang sudah membantu dalam kegiatan penelitian dan penulisan Best Practice ini.

\section{REFERENCES}

Ahmadi, Abu. (1991). Psikologi Perkembangan. Jakarta: Rineka Cipta.

Al-Tabany, Trianto Ibnu Badar. (2017). Mendesain Model Pembelajaran Inovatif, Progresif, dan Kontekstual. Jakarta: Kencana.

Gunarso, Singgih D. (1990). Psikologi Untuk Keluarga. Jakarta: Gunung Mulia. Frans V. Magnis-Suseno, (1985). Etika Umum. Yogyakarta: Kanisius.

Hamalik, Oemar. (2020). Kurikulum dan Pembelajaran. Jakarta. Bumi Aksara.

Hamdani. (2010). Strategi Belajar Mengajar. Bandung: Pustaka Setia.

Huda, Miftahul. (2020). Model-Model Pengajaran dan Pembelajaran Isu-Isu Metodis dan Paramedis. Yogyakarta: Pustaka Pelajar

. Komalasari, Kokom ( 2010). Pembelajaran Kontekstual. Bandung: PT Refika Aditama

Latuheru, John. (1988). Media Pembelajaran Masa Kini. Jakarta: Depdikbud.
Ngalimun. (2015). Strategi dan Model Pembelajaran. Yogyakarta:Aswaja Presindo.

Pimpinan MPR, (2016). Materi Sosialisasi Empat Pilar MPR RI. Yogyakarta: Jakarta.

Rusman. (2016). Model-Model Pembelajaran : Mengembangkan Profesionalisme Guru. Jakarta: Rajawali Pers.

Sani, Ridwan Abdullah. (2013). Inovasi Pembelajaran. Jakarta : PT Bumi Aksara.

Salahudin, Anas. (2013). Pendidikan Karakter Pendidikan Berbasis Agama dan Budaya Bangsa. Bandung: Pustaka Setia

Smaldino, Sharon E, dkk. (2011). Instructional Technology \& Media For Learning Teknologi Pembelajaran dan Media untuk Belajar. Jakarta: Kencana Prenada Media Group.

Sukrima, Syifa S. (2014). 53 Metode Belajar dan Pembelajaran Plus Aplikasinya. Bandung: Indonesia University Of Educations

Sulaiman, Amir Hamsah.(1950). Ilmu djiwa anak-anak. Bandung: Ganesa.

Sundari, Fitri. (2016). Penggunaan Metode Broken Triangle, Square, dan Heart Untuk Meningkatkan Hasil Belajar Peserta didik Pada Mata Pelajaran Bahasa Inggris. Jurnal Studi Pendidikan Islam, 13(1), 19.

Suryono, H. (2005). Hukum kenegaraan dan Perundang-Undangan: Perspektif Sosiologis-Normatif Dalam Teori dan Praktik. Solo: UNS Press.

Winataputra, U.S. (2007). Pendidikan Kesadaran Berkonstitusi: Alternatif Model Pembelajaran Kreatif Demokratis untuk Pendidikan Kewarganegaraan . [Online]. Tersedia:http://www.depdiknas.g o.id . html [4 Desember 2007],

ConflictofInterestStatement:Theauthorsdeclarethat the research wasconducted in the absence of any commercial or financial relationships that could be construed as a potential conflict of interest.

Copyright $@ 2020$ Siti Fatimah. Thisisanopen-accessarticledis- tributed under the terms of the Creative Commons Attribution License (CC BY). The use, distribution or reproduction in other forums is permitted, provided the original author(s) and the copyright owner(s) are credited and that the original publication in this journal is cited, in accordance with accepted academic practice. No use, distribu- tion or reproduction is permitted which does not comply with these terms. 


\section{LIST OF TABLE}

1 Rekap Kesadaran Berkonstitusi.....

2 Hasil Nilai Pengetahuan

11 
TABLE 1/Rekap Kesadaran Berkonstitusi

\begin{tabular}{|c|c|c|c|}
\hline Perilaku & $\begin{array}{c}\text { Model Ceramah (Pertemua } \\
\text { 1) }\end{array}$ & $\begin{array}{l}\text { Model Broken Triangle, Square } \\
\text { dan Heart (Pertemuan 2) }\end{array}$ & $\begin{array}{c}\text { Model Broken Triangle, Square dan } \\
\text { Heart (Pertemuan 3) }\end{array}$ \\
\hline Tidak terlambat masuk kelas & 23 & 28 & 29 \\
\hline Potongan Rambut rapi & 25 & 28 & 30 \\
\hline Seragam Sekolah Beridentitas & 27 & 29 & 29 \\
\hline Tenang di Kelas & 22 & 29 & 30 \\
\hline Memperhatikan Guru & 22 & 30 & 30 \\
\hline Duduk rapi & 24 & 30 & 29 \\
\hline Tidak mengantuk ketika belajar & 28 & 30 & 30 \\
\hline$\Sigma$ Perolehan Perilaku & 171 & 204 & 207 \\
\hline$\Sigma$ Total Perilaku & 210 & 210 & 210 \\
\hline$\%$ & 81,43 & 97,14 & 98,57 \\
\hline
\end{tabular}


TABLE 2/Hasil Nilai Pengetahuan

\begin{tabular}{cccc}
\hline Rentang Nilai & Model Ceramah & Model Broken Triangle, Square dan Heart & Model Broken Triangle, Square dan Heart \\
\hline $96-100$ & 1 & 2 & 11 \\
$91-95$ & 0 & 2 & 0 \\
$86-90$ & 0 & 3 & 3 \\
$81-85$ & 1 & 3 & 7 \\
$76-80$ & 5 & 18 & 1 \\
$71-75$ & 1 & 30 \\
$\leq 70$ & 22 & 66,00 \\
$\Sigma$ Peserta didik & 30 & 11 \\
\hline Nilai rata-rata & 59,47 & 19 \\
\hline Peserta didik Tuntas (\%) & 8 & 30 \\
\hline
\end{tabular}




\section{LIST OF FIGURE}

1 Rekap Kesadaran Berkonstitusi

2 Hasil Nilai Pengetahuan 


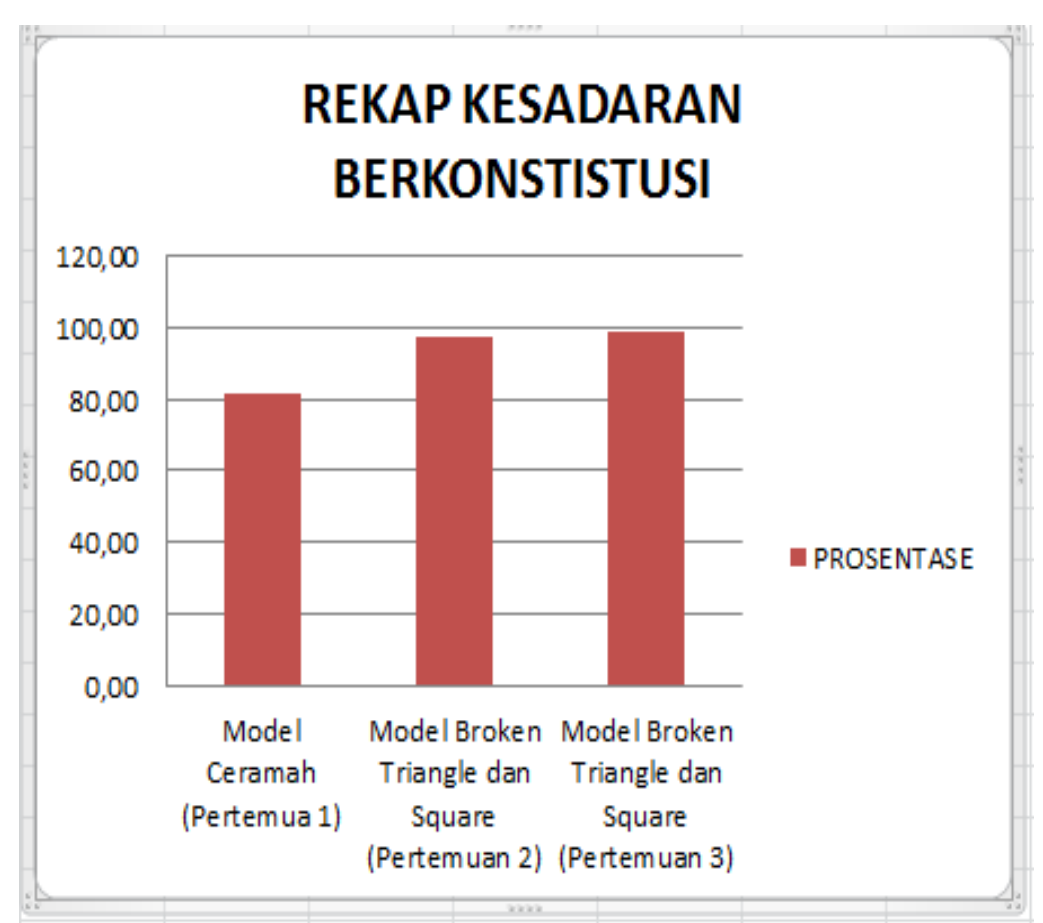

FIGURE 1 / Rekap Kesadaran Berkonstitusi 


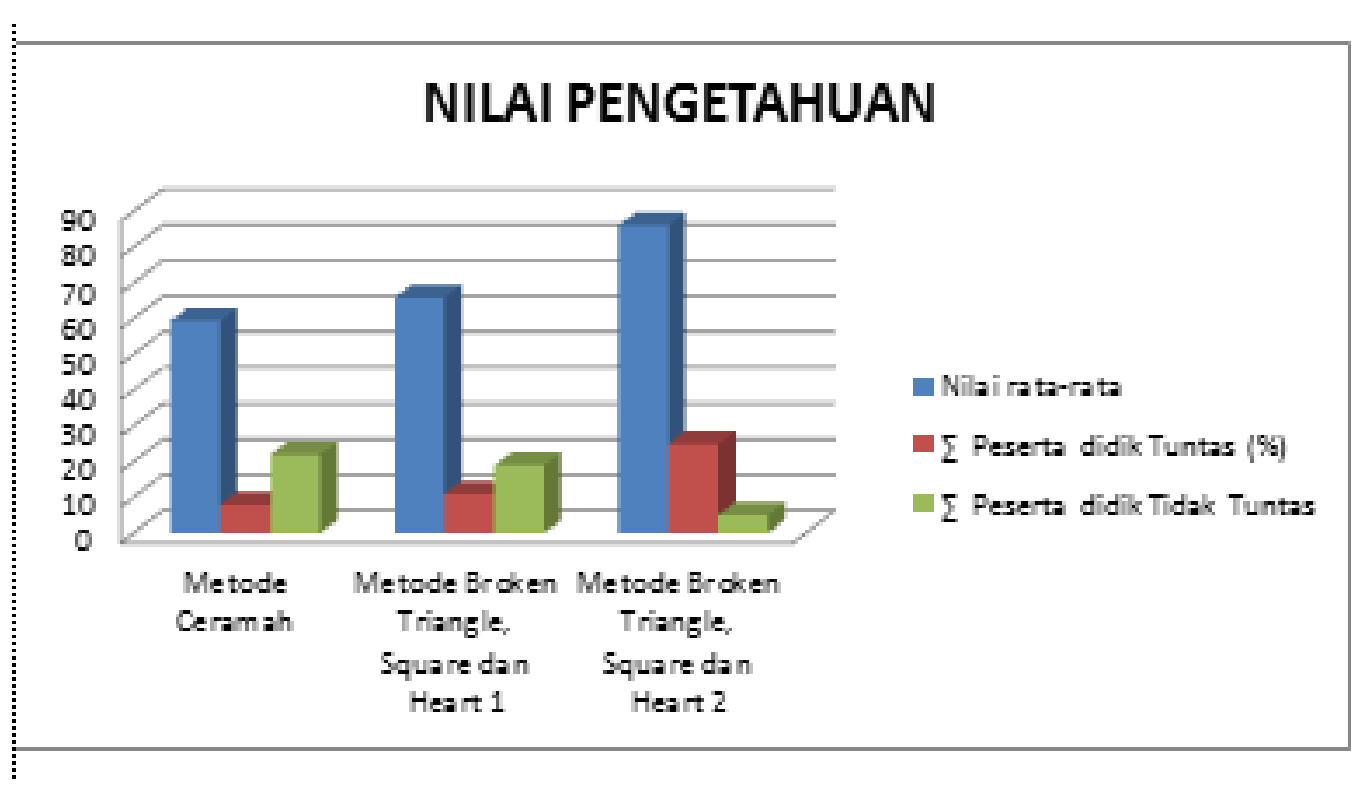

FIGURE 2 / Hasil Nilai Pengetahuan 